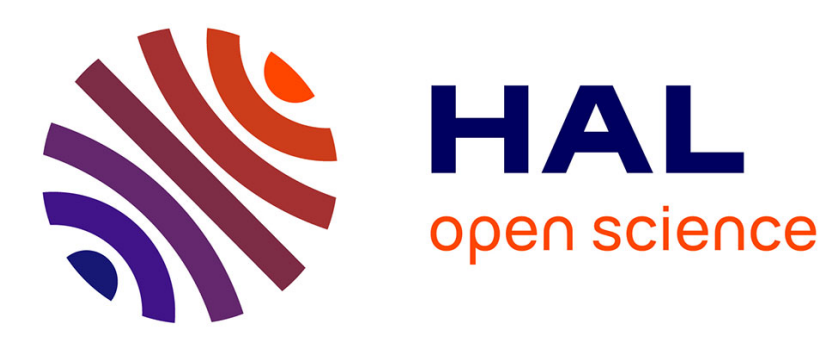

\title{
THE TUNABLE VIBRONIC LASER MATERIALS BASED ON TRANSITION METAL IONS : SEARCH OF NEW SYSTEMS AND EXCITED STATE SPECTROSCOPY
}

\author{
T. Benyattou, R. Moncorge
}

\section{To cite this version:}

T. Benyattou, R. Moncorge. THE TUNABLE VIBRONIC LASER MATERIALS BASED ON TRANSITION METAL IONS : SEARCH OF NEW SYSTEMS AND EXCITED STATE SPECTROSCOPY. Journal de Physique Colloques, 1987, 48 (C7), pp.C7-390-C7-390. 10.1051/jphyscol:1987794 . jpa00227099

\section{HAL Id: jpa-00227099 https://hal.science/jpa-00227099}

Submitted on 1 Jan 1987

HAL is a multi-disciplinary open access archive for the deposit and dissemination of scientific research documents, whether they are published or not. The documents may come from teaching and research institutions in France or abroad, or from public or private research centers.
L'archive ouverte pluridisciplinaire HAL, est destinée au dépôt et à la diffusion de documents scientifiques de niveau recherche, publiés ou non, émanant des établissements d'enseignement et de recherche français ou étrangers, des laboratoires publics ou privés. 
THE TUNABLE VIBRONIC LASER MATERIALS BASED ON TRANSITION METAL IONS : SEARCH OF NEW SYSTEMS AND EXCITED STATE SPECTROSCOPY

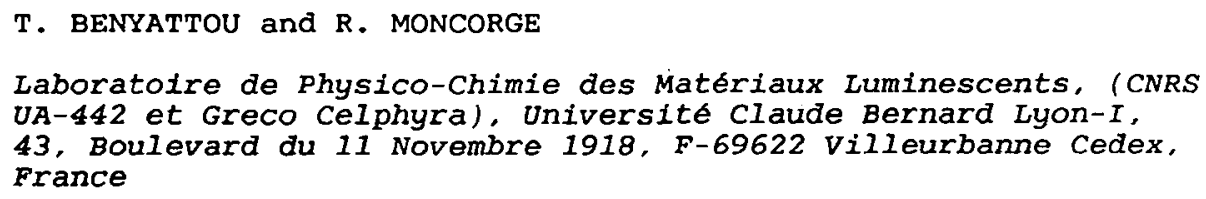

For they are stable and they allow to get intense and tunable radiations in a large spectral domain, the vibronic solid state laser materials based on transition metal ions such as $\mathrm{Ti}^{3+}, \mathrm{Cr}^{3+}, \mathrm{V}^{2+}, \mathrm{Ni}^{2+}$ and $\mathrm{Cu}^{2+}$ give rise presently to a renewed and increased interest, and more particularly in our laboratory as concerns the optical studies.

In this presentation, a first part is dealing with the description of the active mediun and the worlcing basis of this type of laser, by showing, for example, the importance of the thermal effects. on the laser characteristics. He will also point out briefly on the state of the art of these laser materials.

A second part will be devoted to the description of our specific ains : search of new systems, ${ }^{(t)}$ classical as well as elaborated optical studies such as measurements of fluorescence quantum efficiencies and measurements of excited-state absorption cross sections, modelization of the dynamical processes, optimization of the laser performance and use of the best systems in appropriate optical cavities. (t+)

\footnotetext{
+ in collaboration with b.Vivien and A.M. Lejus (ENSCP, Paris) ++ thanks to a DiEl Grant B1/071
} 